\title{
Disruption of a Regulatory Network Consisting of Neutrophils and Platelets Fosters Persisting Inflammation in Rheumatic Diseases
}

\author{
Norma Maugeri*, Patrizia Rovere-Querini and Angelo A. Manfredi \\ San Raffaele Scientific Institute, Università Vita Salute San Raffaele, Milano, Italy
}

A network of cellular interactions that involve blood leukocytes and platelets maintains vessel homeostasis. It plays a critical role in the response to invading microbes by recruiting intravascular immunity and through the generation of neutrophil extracellular traps (NETs) and immunothrombosis. Moreover, it enables immune cells to respond to remote chemoattractants by crossing the endothelial barrier and reaching sites of infection. Once the network operating under physiological conditions is disrupted, the reciprocal activation of cells in the blood and the vessel walls determines the vascular remodeling

Edited by:

Rudolf Lucas,

Medical College of Georgia, USA

Reviewed by:

Matthias Clauss,

Indiana University, USA

Jo A. Van Ginderachter,

VIB-Vrije Universiteit Brussel, Belgium

Juerg Hamacher,

Lindenhof Hospital, Switzerland

*Correspondence:

Norma Maugeri

maugeri.norma@hsr.it

Specialty section:

This article was submitted to Inflammation,

a section of the journal

Frontiers in Immunology

Received: 29 January 2016

Accepted: 29 April 2016

Published: 19 May 2016

Citation:

Maugeri N, Rovere-Querini $P$ and Manfredi AA (2016) Disruption of a Regulatory Network Consisting of

Neutrophils and Platelets Fosters Persisting Inflammation in Rheumatic

Diseases.

Front. Immunol. 7:182. doi: 10.3389/fimmu.2016.00182 via inflammatory signals delivered to stem/progenitor cells. A deregulated leukocyte/ mural cell interaction is an early critical event in the natural history of systemic inflammation. Despite intense efforts, the signals that initiate and sustain the immune-mediated vessel injury, or those that enforce the often-prolonged phases of clinical quiescence in patients with vasculitis, have only been partially elucidated. Here, we discuss recent evidence that implicates the prototypic damage-associated molecular pattern/alarmin, the high mobility group box 1 (HMGB1) protein in systemic vasculitis and in the vascular inflammation associated with systemic sclerosis. HMGB1 could represent a player in the pathogenesis of rheumatic diseases and an attractive target for molecular interventions.

Keywords: platelets, neutrophils, HMGB1, inflammation, rheumatic diseases

\section{NEUTROPHILS, PLATELETS, AND VASCULAR INFLAMMATION}

Neutrophils are terminal cells with a relatively short half-life in the circulation. They are effective as a first barrier toward various invading noxae. To carry out this function, neutrophils cross the vessel wall and migrate to the inflamed/injured tissues. This step requires the recognition of P-selectin on the activated endothelium and the asymmetric polarization of the leukocyte $\beta 2$ integrins that generates the unidirectional movement associated with the infiltration of the surrounding perivascular tissues. These events influence the immune function of transmigrating leukocytes, thus contributing to the overall outcome of the inflammatory response: effective resolution versus persistence of vascular inflammation, healing of the injured vessel wall versus active remodeling, intimal hyperplasia, or aneurism formation. Conversely, transmigrating neutrophils both damage and activate endothelial cells, enforcing a self-sustaining positive feedback loop that contributes for example in patients with systemic small-vessel vasculitis or with systemic sclerosis (SSc) to vascular remodeling and inflammation (1-4). 
At sites of infection, neutrophils dispose of invading microorganisms. This action depends partially on the engulfment into a phagosome upon reorganization of the actin-based cytoskeleton and on the activation of the NADPH oxidase system with generation of reactive oxygen species (ROS) $(5,6)$. The oxygen species combined with the granules microbicidal moieties released into the phagolysosome limits the pathogen viability (6-8). Non-phagocytic neutrophils' microbicide mechanisms have also been described, which involve the release of decondensed chromatin threads in the extracellular space. This phenomenon is referred to as neutrophil extracellular traps (NETs) generation (8-11). Neutrophils preferentially generate NETs when they fail to engulf the pathogen because they are immobilized, tightly adherent to a substrate, or near to apoptosis $(8,12-15)$. Primary granules fuse with the nuclear membrane, causing the formation of myeloperoxidase-DNA and elastase-DNA complexes (14), while the physicochemical properties of the chromatin change dramatically upon the citrullination of histones by the peptidylarginine deiminase 4 (PAD4) enzyme $(16,17)$. Both granule redistribution and PAD4-mediated histone citrullination are required for NET generation. During experimental sepsis, NETs play a role in bacterial trapping ensnaring circulating bacteria and restricting their dissemination to distant organs (18).

Neutrophils and platelets colocalize at sites of vascular injury, hemorrhage, and thrombosis. In these conditions, various inflammatory and thrombogenic signals are integrated, resulting in the productive interaction between platelets and leukocytes, yielding the formation of aggregates $(15,19,20)$. Neutrophils/platelets heterotypic aggregates depend on platelet P-selectin, are endowed with inflammatory and thrombogenic actions, and represent a shared feature of acute cardiovascular diseases and of systemic inflammatory, neoplastic, and autoimmune diseases (21).

Upon platelet adhesion to damaged vessel walls, P-selectin expressed on their surface facilitates the leukocyte recruitment at the site of vascular injury. Signals activated downstream the recognition of platelet $\mathrm{P}$-selectin promote the generation of ROS $(5,22)$, the activation of $\beta 2$ integrins $(2,7,15,23,24)$, the release of pentraxin 3 from the neutrophil specific (secondary) granules (25), the release of myeloperoxidase from the azurophilic (primary) granules $(6,25,26)$, and the de novo synthesis and the surface expression of leukocyte tissue factor $(1,2,21)$ (Figure 1).

Additionally, activated platelets release soluble inflammatory signals, including IL-1 $\beta$, PDGF, and the prototypic endogenous immune adjuvant, the high mobility group box 1 (HMGB1) protein $(5,27,28)$. Finally, the inflammatory action of platelets is amplified and sustained by the release of bioactive microparticles $(5,20,27,29,30)$. Microparticles comprise small vesicles (usually ranging from 0.05 to $1 \mu \mathrm{m}$ ) shed from activated or dying cells as a consequence of the disruption of the pathway actively maintaining the asymmetry between the phospholipid layers of the plasma membrane. Most microparticles in the blood derive from platelets (30). Platelet-derived microparticles participate in blood coagulation and actively contribute to the inflammatory action of platelets (30). The array of signals expressed, generated, or released by platelets upon activation acts mostly locally influencing the microenvironment. However, these signals possibly

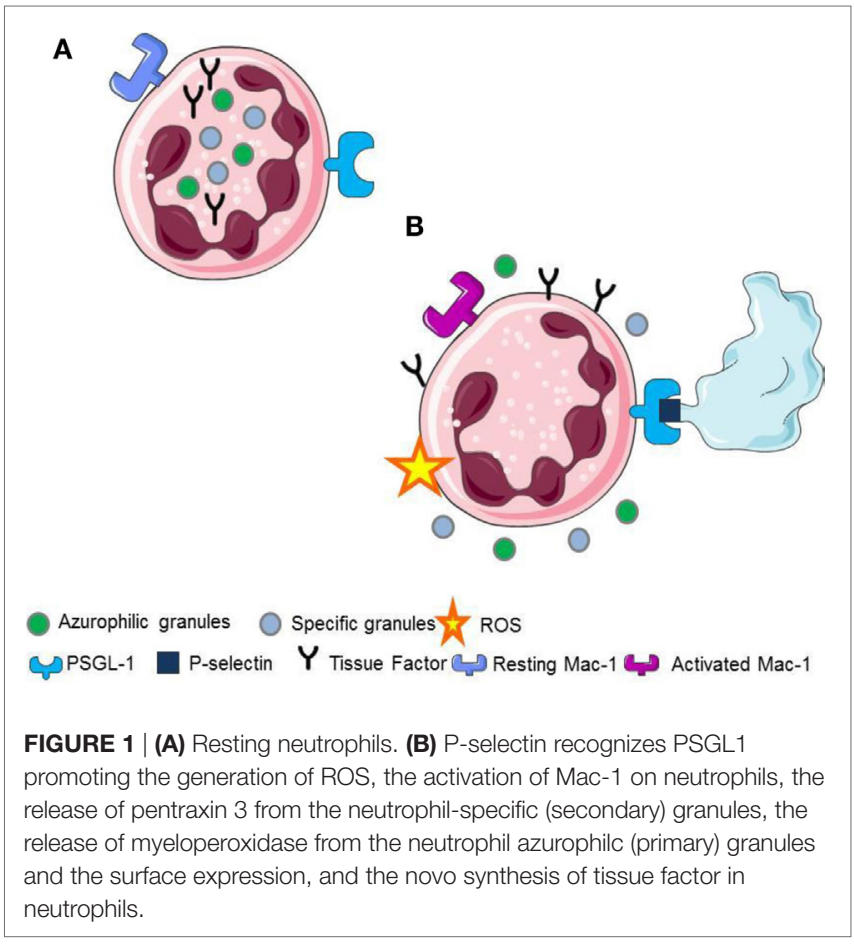

influence the leukocyte function in the circulation, in particular in patients with systemic vasculopathy $(2,31)$.

Of importance, the dangerous connection between neutrophils and platelets can have different outcomes depending on the context. These outcomes include the phagocytic removal of platelets in physiological conditions (6). Upon inflammatory conditions, adherent neutrophils recognizing activated platelets are committed to NET generation $(12,20,32)$.

\section{NETS CONTRIBUTE TO PROPAGATE VASCULAR INJURY AND AUTOIMMUNITY}

Neutrophil extracellular traps generation comprises a physiological response of living neutrophils to various stimuli present in a specific environmental context $(11,12,20,33)$ or a form of cell death that is morphologically distinct from apoptosis $(34,35)$. The mechanisms regulating the type of NET formation seem to depend on the triggering stimuli and on the context of stimulation. They comprise (i) the production of ROS and the induction of autophagy, (ii) the fusion of primary granules with nuclear membrane, (iii) the interaction of elastase and MPO with the DNA, (iv) the citrullination of histones, the chromatin decondensation, and, finally, (v) the nuclear envelope and, eventually, the cell membrane integrity disruption (10, 34, 36) (Figures 2 and $\mathbf{3}$ ).

The ensuing prolonged exposure of neutrophil microbicidal proteins as well as of citrullinated histones in the extracellular environment could initiate autoimmunity $(4,10,37,38)$. NETs are cleared via a mechanism involving DNAses and the first component of the classical pathway of complement activation, C1q. As a consequence, the endocytotic/phagocytotic function of scavenger macrophages limits NETs inflammatory and 

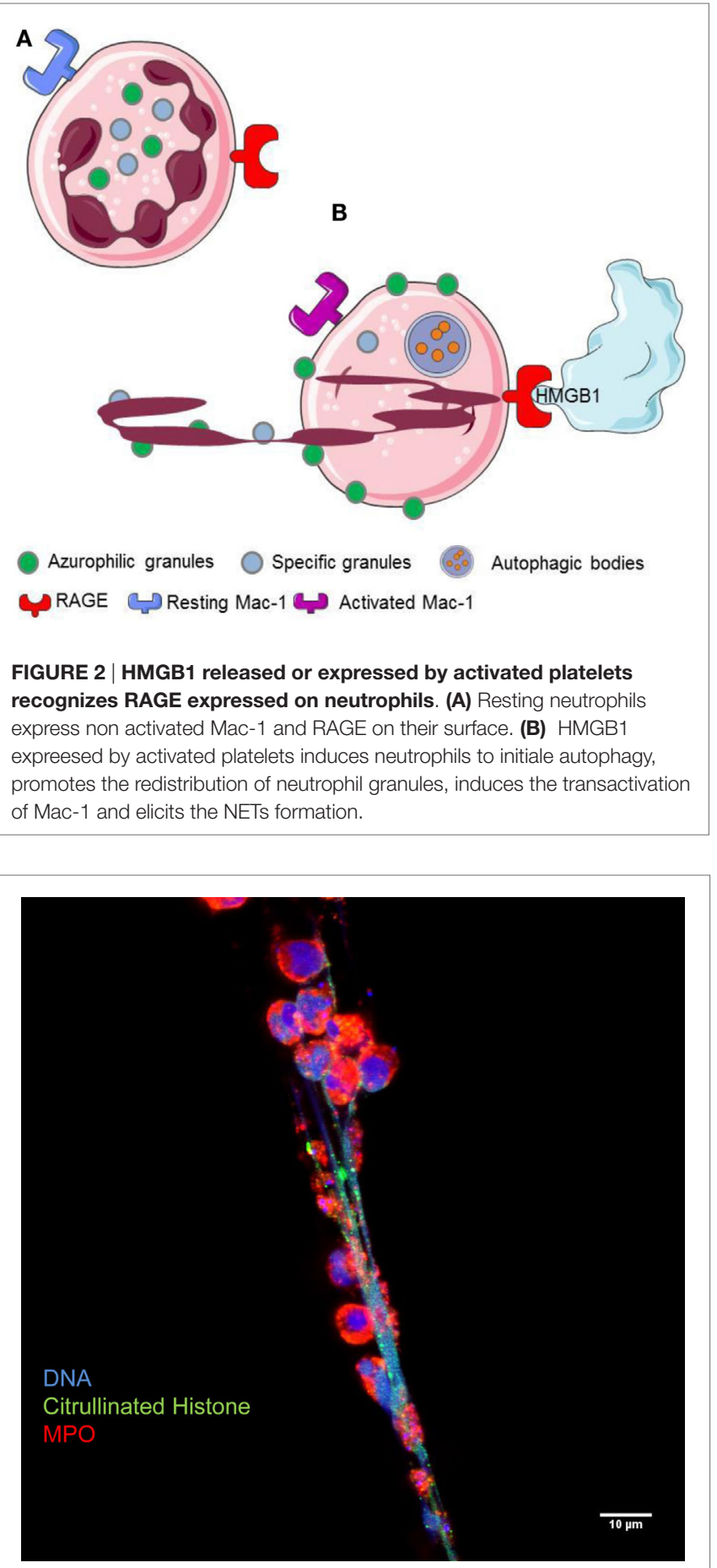

FIGURE 3 | Neutrophil extracellular traps are characterized by decondensed latices of DNA with citrullinated histones decorated with neutrophil granules proteins, such as myeloperoxidase. Originally published by Maugeri et al. (20).

potentially vessel-injuring properties $(39,40)$. Moreover, persistence of NETs in the tissue might prompt fibrosis via induction of myofibroblasts (41).

In contrast, defective clearance of NETs and activation of the alternative pathway of complement activation might be associated with persisting tissue damage and to autoimmunity (10, 42-46). Accumulation in the plasma of byproducts of NET generation/ catabolism (such as complexes of DNA-MPO or soluble DNA with citrullinated histones), higher capacity of in vitro NETs generation, and an impaired capacity of NETs degradation were observed in patients with systemic lupus erythematosus (SLE), small vessel vasculitis, rheumatoid arthritis, and psoriasis (47), while the association of biologically active moieties, such as tissue factor, TNF $\alpha$ and IL-1 $\beta$, with NETs might influence their action in the microenvironment $(48,49)$.

The formation of NETs in vivo seems to be directly associated with SLE. Accordingly with this hypothesis, in an animal model of lupus, the effective inhibition of PAD4 results both in a reduction of NET formation and in altered circulating autoantibody profiles, restored complement levels, and reduced glomerular IgG deposition $(37,38,50)$.

\section{ENDOGENOUS MECHANISMS MAINTAINING VASCULAR INFLAMMATION: A ROLE FOR HMGB1}

High mobility group box 1 has been named after its ability to quickly migrate in polyacrylamide and triton-urea gels, a feature that depends on a high-content of charged amino acid residues. HMGB1 is located on the $13 \mathrm{q} 12$ human chromosome. The gene comprises six exons that encode for a 215-amino acid polypeptide, with an apparent molecular mass of $25 \mathrm{kDa}$. HMGB1 proteins from mammals are nearly identical, indicating that each residue is under selective pressure. In general, the cell type and state of activation influence levels and localization, and more differentiated cells display a lower protein content. HMGB1 consists of a long acidic carboxyterminal region (the "acidic tail") and of two positively charged domains, referred to as "box A" and "box $\mathrm{B}$," that bind to DNA and contain nucleus localization signals. HMGB1 is mostly located in the nucleus of most living cells where it bends DNA, thus facilitating the assembly of proteins, including transcription factors, on their targets. HMGB1 moves constantly from the nucleus to the cytoplasm $(51,52)$. In response to stress, senescence, or inflammatory signals, HMGB1 is hyperacetylated at two sites in nuclear localization, and this isoform accumulates in the cytoplasm (53). HMGB1 in the cytoplasm promotes autophagy, by which cells recycle internal constituents so as to generate ATP and promote survival under conditions of environmental stress (51).

The interaction with the chromatin in living cells is transient, and HMGB1 plays relevant biological functions in the cytosol, where it behaves as a potent inductor of autophagy (54). Cell death via an unscheduled accidental pathway, which associates with the disruption of membrane compartmentalization, results in the redistribution of the molecule at extracellular sites, where HMGB1 behaves as a potent inflammatory signal $(51,55)$. Most activated cells also mobilize HMGB1. Monocytes, macrophages, and immature myeloid and plasmacytoid dendritic cells (DCs) secrete HMGB1 in response to primary inflammatory signals. Anucleated platelets also contain and upon activation release substantial amount of HMGB1, either as a soluble moiety or associated with microparticles $(5,20,27,28)$. HMGB1 released 
or expressed by activated platelets commits neutrophils to autophagy (20), promotes the redistribution of neutrophil granules (5), induces the Mac-1 transactivation (5), and elicits the NETs formation $(20,56,57)$ (Figure 2).

Posttranslational modifications, such acetylation, phosphorylation, methylation, and oxidation/reduction (58-61), and the interaction with other bioactive molecules, including LPS or chemokines $(62,63)$, CXCL12 in particular $(64,65)$, all influence the function of extracellular $\operatorname{HMGB} 1(5,58,66)$. The redox status of the three cysteine residues of the molecule (C23, C45, and C106) apparently dictates the sequential events of leukocyte recruitment, activation, and resolution of inflammation (59). The characteristics of HMGB1 biology, including its association with various events important in the natural history of vasculitis, such as necrosis, granuloma formation, and leukocytes survival and activation, as well as its ability to regulate inflammation and tissue repair and remodeling, make the protein a candidate player in this family of diseases.

Acute vascular inflammation has a well-characterized homeostatic role. Defects in the program result in self-sustaining vascular inflammatory diseases, referred to as vasculitis. Indeed, an unrelenting inflammatory process mostly restricted to the vessel wall characterizes large vessel vasculitis [Takayasu arteritis, giant-cell arteritis (GCA)] $(3,67)$. The productive interaction between activated adventitial DCs and T cells is an early and crucial event. The local production of $\mathrm{T}$ cells cytokines eventually results in IFN $\gamma$-mediated activation of macrophages and in the formation of giant cells at the intima-media junction. Giant cells and activated macrophages produce growth factors (such as vascular endothelial growth factor and platelet-derived growth factors), which sustain intimal hyperplasia and contribute to subsequent end organ ischemia (68). Circulating blood cells are also activated and might contribute to the clinical picture. For example, thrombocytosis is frequent in GCA patients $(69,70)$, and aspirin protects patients from cranial ischemic complications (1, 71-74). Aspirin-resistant events are, however, quite frequent, and platelet count does not identify patients at higher risk of severe ischemic events (74-76).

Blood cells of GCA patients express tissue factor, a key molecule in thrombin formation downstream activation of Factor VII, and display a greater fraction of platelets expressing P-selectin, which is associated with a procoagulant state $(1,77)$. Specific clinical features or the extent of biomarkers of systemic inflammation, which, however, may fail to reveal the extent of ongoing smoldering vascular inflammation (78), do not apparently influence these features (3). Despite extensive investigations, markers reflecting not exclusively inflammation but the extent of the process taking place in the affected vessels have proved elusive, with the possible exception of the soluble pattern recognition receptor PTX3, which is produced in peripheral tissues in response to signals of injury by innate immune cells, such as DCs and macrophages $(79,80)$.

Dendritic cells and macrophages are a critical source of HMGB1, which shapes their functional polarization and migratory properties (81-85). While PTX3 plasmatic levels seem to be associated with the entity of the disease $(79,86,87)$, concentrations of HMGB1 in the blood are not an effective biomarker of large vessel vasculitis (88). Indeed, patients with Takayasu's arteritis and GCA present similar serum HMGB1 levels compared with healthy controls and seem unrelated to disease activity (88).

However, it should be considered that several posttranslation modifications influence the bioactivity of the molecule. Specifically environmental conditions, such as the redox status, influence HMGB1 inflammatory action, causing the shift from a moiety that mostly causes leukocyte recruitment or to a signal that elicits the secretion of inflammatory cytokines (53), see above. As such, the total concentrations of the molecule in the blood might not reflect the actual fraction of the bioactive molecule (5, $53,59)$. When potent inflammatory molecules are released in the environment, inhibitors are often physiologically generated, like it occurs for the primary inflammatory cytokines, TNF $\alpha$ and IL-1 $\beta$. The identification of putative HMGB1 inhibitors requires further study. The development of analytical techniques to discriminate among the various forms of HMGB1 might allow to dissect the actual HMGB1 involvement in the various facets of vascular inflammation: effective repair of injured vessels, angiogenesis, persistent inflammation with extensive remodeling, aneurysm formation, development of atherosclerotic lesions, complications associated with their disruption, etc. (89).

Leukocytoclasia (i.e., the presence of of uncleared leukocyte debris within and around the vessel wall), small-vessel thrombosis, necrosis, and hemorrhage in target organs (mainly the skin, the kidneys, and the airways) are hallmarks of small-vessel vasculitis. Immune complexes play a major role in eliciting vascular inflammation during some small-vessel vasculitis (IgA vasculitis or cryoglobulinemia, for example), and immunoglobulin and complement deposition at the site of vascular injury accompanies in these patients' leukocytoclasia. In contrast, a "pauci-immune" inflammation, without local immunoglobulin or complement deposition, characterizes vasculitis syndromes associated with antineutrophil cytoplasmic antibodies (ANCA-associated vasculitis). Elevated levels of plasmatic HMGB1 have been found in patients with small-vessel vasculitis, including IgA vasculitis, Kawasaki's disease, and ANCA-associated vasculitis (90-93). The concentration of plasmatic HMGB1 is elevated in the active phase of systemic vasculitis, and the concentration of HMGB1 is higher in patients with granulomatosis with polyangiitis with a predominantly granulomatous disease (94). In contrast, conventional markers of inflammation or the validated disease activity score, BVAS, fail to discriminate between the two groups of patients (94). The result well fits the preferential expression of the HMGB1 in the granulomatous tissue (94) and suggests that systemic levels might actually reflect local in situ production. HMGB1 levels are also been described to be higher in patients with active renal involvement, a threatening manifestation of the disease (90). Levels of HMGB1 are still elevated in patients with a quiescent nephritis, possibly indicating a persistent low-grade inflammation that persists in the subclinical phases of the disease (90). Urinary levels of HMGB1 represent a robust biomarker of active glomerulonephritis in patients with ANCA-associated vasculitis $(42,95)$. Actually, urinary HMGB1 might represent a more solid biomarker of kidney involvement in ANCA-associated vasculitis than serum HMGB1 (96).

The preferential involvement of HMGB1 in ANCA-associated vasculitis might be related to its ability to regulate the activation 
state and function of neutrophils, which are the key cells in the pathogenesis of these diseases. Of interest, HMGB1 could contribute as inflammatory priming of neutrophils in circulation, inducing translocation of ANCA antigens at cell membrane, providing the substrate of antigen-antibody interactions (97).

The recognition of extracellular HMGB1 dramatically influences several characteristics of neutrophils, a key population in ANCA-associated small-vessel vasculitis. It induces a swift redistribution of intracellular vesicles, an event that might be associated with the ability to activate neutrophil autophagy (5) through the putative HMGB1 receptor, the receptor for advanced glycation endproducts (RAGE) (Figures 2 and $\mathbf{4}$ ).

The redistribution of the granule in response to primary inflammatory stimuli allows the exposure of ANCA antigens (namely, myeloperoxidase and proteinase 3) on the neutrophil plasma membrane, where they become accessible for interaction with the ANCA autoantibodies because of a preferential location at lipid rafts that also contain $\beta 2$ integrins, signalling molecules, cross-linked Fcgamma receptors, and NADPH oxidase. ANCA, in turn, amplify the activation of the neutrophil, which is transmigrating, favouring a vigorous and untimely response, with oxidative burst and premature degranulation (97, 98). HMGB1 might, thus, act on neutrophils favouring the exposure of ANCA antigens and facilitating the further neutrophil activation caused by the antigen recognition by ANCAs. Of importance, HMGB1 has been recently shown to potentiate the NETs formation induced in the presence of ANCAs (99).

\section{HMGB1 AND DIABETIC VASCULOPATHY}

High mobility group box 1 elevation appears as a relatively shared feature in patients with an inflammatory vascular involvement. This applies not only to other primary vasculitides $(91,100,101)$ but also to other systemic diseases characterized by extensive inflammatory vessel involvement (102). Diabetes mellitus represents a privileged scenario for the study of the role in vascular inflammation of HMGB1 and of the RAGE receptor. The systemic HMGB1 concentration is consistently elevated in diabetic patients and in animal models of the disease $(103,104)$. HMGB1 might contribute to the accelerated atherosclerosis, which is a hallmark of diabetes mellitus (105-107). Hyperglycemia is an effective stimulus leading the release of HMGB1, which in turn might play
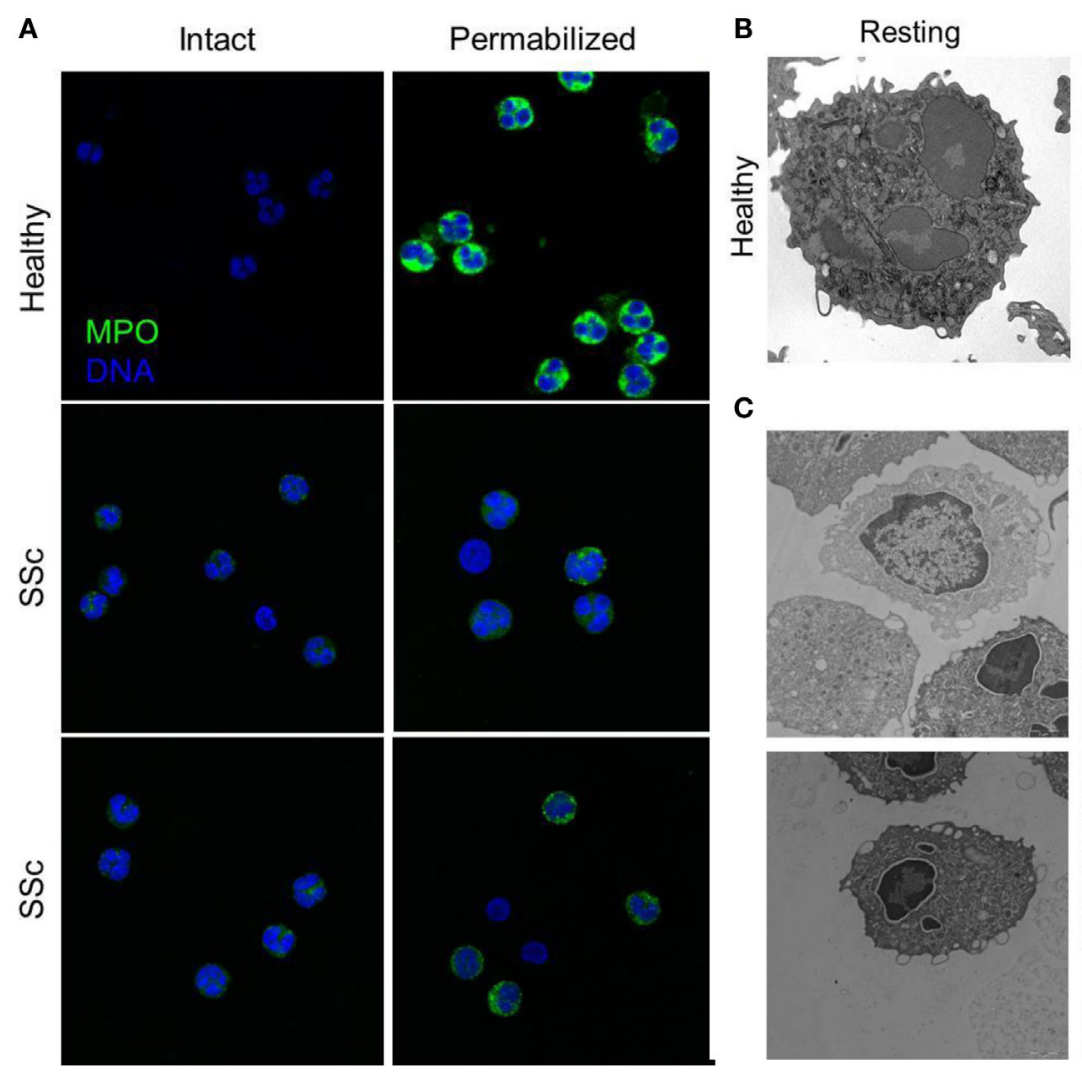

Primed with HMGB1

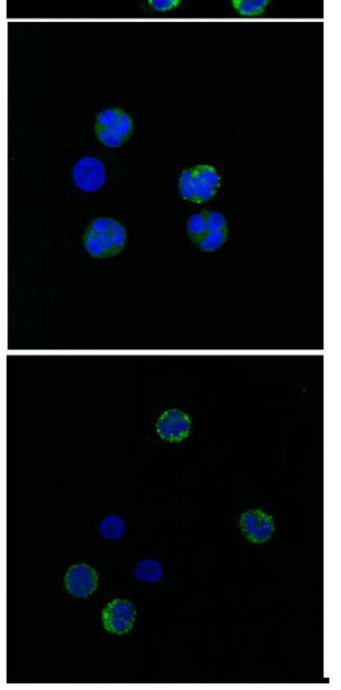

C
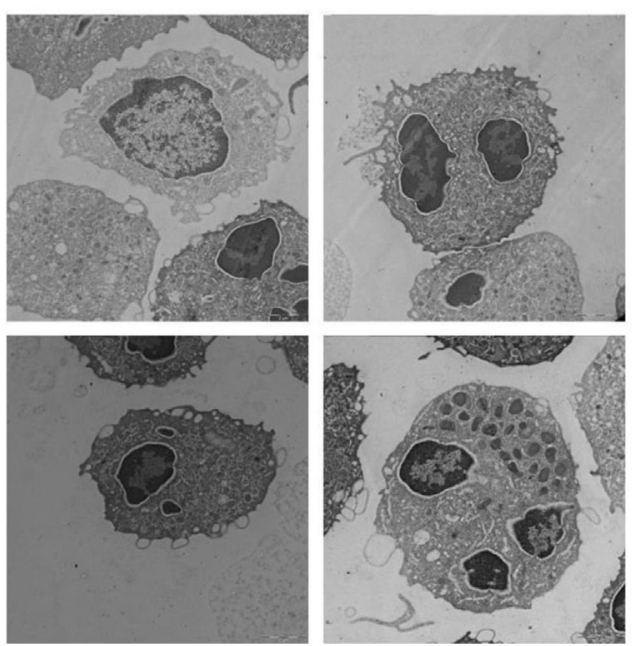

FIGURE 4 | Peripheral granules distribution characterized neutrophils of patients with SSc. (A) The expression of MPO (green) in the blood neutrophils of patients with SSc and of matched controls has been analyzed by confocal microscopy before and after permeabilization of the plasma membrane, to allow the access of the mAb. MPO intracellular expression is substantially lower in SSc patients and appears to cluster at the plasma membrane of intact, non permeabilized neutrophils. (B,C) Representative images by electron microscopy of neutrophils from a healthy control, untreated or treated with HMGB1 (B) or of untreated neutrophils from four SSc patients (C) showing the extensive remodeling of intracellular granules, most of which acquire a pericellular distribution, characterizes SSc neutrophils and healthy neutrophils treated with HMGB1. Images originally published by Maugeri et al. (5). 
a role in the failure of tolerance in diabetes mellitus type 1 (108, $109)$ and in the early rejection of transplanted islets $(110,111)$. Furthermore, glycated albumin is recognized by RAGE inducing the neutrophil activation and release of NETs (20).

\section{HMGB1 AND SYSTEMIC SCLEROSIS}

Systemic sclerosis is an immune-mediated multisystem disease, characterized by a diffuse obliterative microvasculopathy and by fibrosis of the skin and of visceral organs. The abnormal generation of ROS observed in patients with SSc contributes fostering autoimmunity, fibrosis, and vascular inflammation. Recently, the presence of an increased concentration of platelet-derived microparticles $(\mathrm{PD} \mu \mathrm{P})$ bearing $\mathrm{HMGB} 1, \mathrm{P}$-selectin expressing platelets $(5,27)$, the redistribution of the content of primary granules, and the transactivation of $\beta 2$ integrins leukocytes was observed in blood cells of SSc patients (Figure 4). P-selectin (purified or expressed on activated platelets) induces the ROS generation by neutrophils, which in turn cause the oxidation of the HMGB1 expressed by $\mathrm{PD} \mu \mathrm{P}$. Oxidation amplifies the ability of HMGB1-expressing $\mathrm{PD} \mu \mathrm{P}$ to activate neutrophils, favoring the redistribution of molecules present in the neutrophil primary granules to the plasma membrane and the transactivation of $\beta 2$ integrins. Leukocyte activation caused by oxidized extracellular HMGB1 abates in the presence of inhibitors of HMGB1 or of catalase, which catalyzes the dismutation of hydrogen peroxide into water and molecular oxygen. Neutrophils from healthy donors challenged with $\mathrm{HMGB} 1$-expressing $\mathrm{PD} \mu \mathrm{P}$ purified from SSc patients, but not those purified from control subjects, reproduce the phenotype of neutrophils of SSc patients, whereas HMGB1 inhibitors reverse the effects of microparticles $(5,27)$. These results suggest that HMGB1 might represent a crucial signal in the cross talk between platelets and leukocytes in SSs, thus sustaining microvascular inflammation. Its ability to promote epithelial and endothelial to mesechimal transition might further link vascular inflammation to the other prominent feature of SSc, fibrosis (112).

\section{HMGB1: A PLAYER IN ANGIOGENESIS AND THROMBOSIS}

Platelet-derived HMGB1 appears as a crucial signal in the cross talk between platelets and leukocytes with potent and specific effects in the regulation of the ability of neutrophils to generate NETs and to activate the autophagic flux (20).

Neutrophil extracellular traps have a well-characterized role in thrombosis, and HMGB1 appears as a player in coronary thrombi formation in patients with acute myocardial infarction (20). A primary role of platelet-derived HMGB1 in thrombosis induction has been confirmed in an elegant genetic model relying on transgenic mice in which the molecule has been specifically ablated (56).

Mechanical or immune-mediated injury of vessels and ischemia/reperfusion cause HMGB1 release (113-117). HMGB1 blockade substantially improves the clinical outcome in several such models, indicating that HMGB1 broadcasts news of ongoing tissue injury and is involved in the ensuing inflammatory response. HMGB1 acts on virtually all cell populations involved in vascular inflammation. It is produced by injured endothelial cells and attracts endothelial cell precursors, which favor neovascularization. HMGB1 overexpression activates a pro-angiogenic program in endothelial cells, mediated via the increased activity of matrix metalloproteinases, of intregrin receptors, and the activation of the NF- $\kappa$ B pathway (118).

Thus, HMGB1 might represent a crucial event to switch the homeostatic inflammatory response to acute vessel injury to selfsustaining vasculitis (3). DCs play a critical role in the establishment of small vessel vasculitis $(85,119-121)$ and in the vessel wall inflammation, which characterize large vessel vasculitis $(122,123)$. HMGB1 prompts its own autocrine/paracrine release, enforcing a vicious circle, which is further amplified by other cytokines known to elicit HMGB1 release, including IL- $1 \beta$ and TNF- $\alpha$ (55, $82,83)$. Finally, the ability of HMGB1 to prompt angiogenesis [see above and Ref. (124)] and to attract vessel-associated stem cells (125) might contribute to intimal hyperplasia/neo-angiogenesis, typical of vessel remodeling during large artery vasculitis.

The events that are implicated in this amplificatory loop associated are not completely characterized. For example, pericellular myeloperoxidase distribution could directly implement the HMGB1/RAGE pathway (5), since the myeloperoxidase system of human neutrophils generates $N^{\prime \prime}$-(carboxymethyl) lysine, a highly reactive advanced glycated end product and RAGE-ligand, at sites of inflammation (126).

Thrombosis is a common and often underestimated complication of ANCA-associated vasculitis (127, 128). Thrombosis occurs as a clinically apparent event and can often in active lesions biopsies be identified at the microscopic levels (129). A study comparing platelet and neutrophil activation of patients with acute coronary syndromes and autoimmune diseases demonstrated that the average of neutrophil myeloperoxidase content in patients with ANCA-associated vasculitis is similar to the one observed in patients with no segment $\mathrm{T}$ elevation myocardial infarction or unstable angina, while the fraction of neutrophil expressing the activated isoform of Mac-1 and platelets expressing P-selectin is similar to all acute coronary syndromes studied (26). Enhanced concentrations in the blood of markers of platelet activation, soluble P-selectin, and CD154 directly correlate with disease activity in large cohort of patients with granulomatosis with polyangiitis (130) [see also Ref. (26)]. P-selectin and CD154 are both involved in the physical interaction and mutual activation of platelets and neutrophils. Their increased turnover in patients with ANCA-associated vasculitis might reflect the link between vascular damage and thrombosis (3). Disrupted endothelial layers recruit and activate platelets, with ensuing activation of the coagulation system cascade. Moreover, platelet P-selectin expression compensates for the lack of endothelial P-selectin, making neutrophil rolling and extravasation possible [discussed in Ref. $(7,131)]$. Neutrophil activation implies the release of protease, which contribute to platelet P-selectin and CD154 cleavage, whose circulating levels consequently increase.

High mobility group box 1 acts as a prototypic agonist for a variety of innate receptors, including RAGE, TLR2, TLR4, TLR9, TREM1, and Mac-1. Via these receptors, HMGB1 in pathological conditions perturbs vessel integrity and contributes to maintain the vicious cycle by which the inflamed endothelium increases the adhesion and the transmigration of leukocytes, and leukocytes, in 
turn, sustain the activation of endothelial cells, eventually leading to cell death and to the activation of programs that might sustain further vessel injury and thrombosis, such as the generation of NETs (132-134).

\section{ENDOTHELIAL RESPONSE TO HMGB1}

Endothelial cells express are exquisitely sensitive to extracellular HMGB1. They express an array of HMGB1 receptors, which comprises RAGE, TLR2, TLR4, TREM1, proteoglycans, and thrombomodulin. The outcome of HMGB1 recognition by endothelial cells dramatically differs depending on which receptors are activated in the various conditions (135). A net activatory effects apparently ensues TLR2 or TLR4 activation, as assessed by the upregulation of adhesion molecules, by the production of cytokines, by the increased vascular permeability, by the activation of the coagulation system, resulting in certain conditions in microvascular thrombosis. HMGB1 not only per se activates endothelial cells $(136,137)$ but also behaves as a general adaptor of the ability of the endothelia to response to various sterile noxious signals. For example, uric acid recruits a complex series of events, including the enhanced expression of the HMGB1-mRNA, the acetylation of HMGB1, its translocation to the cytoplasm, and eventual release. In turn, HMGB1 recognition activates a positive feedback loop causing further HMGB1 expression and release (117).

The outcome of HMGB1 recognition by endothelial cells is finely regulated: this is expected, given the abundance of the molecule and the relatively easy access to the extracellular environment in case of cell activation or death. This might imply the recruitment of pathways that protect the host against the inflammatory action of endogenous components, in particular the CD24-Siglec pathway $(138,139)$ or the thrombomodulindependent pathway. Thrombomodulin is an evolutionary conserved glycosylated type I transmembrane protein with multiple functional domains, which is expressed by endothelial cells, endowed with anticoagulant actions. The thrombomudulin/thrombin complex activates protein $\mathrm{C}$ and in the presence of protein S interferes with factors VIIIa and Va and quenches thrombin generation (140). Thrombomulin ensures vessel homeostasis under stress and a rapid and localized inflammatory response to injury. Indeed, besides thrombin, thrombomodulin interacts via independent domains with various other molecules, including fibrinolysis inhibitors, complement components, and HMGB1. The interaction of HMGB1 with the lectin-like domain of thrombomodulin attenuates inflammation. This might be due to interactions with intermediary proteins that quench the endothelial cell activation $(140,141)$. Moreover, the binding to the lectin-like domain of thrombomodulin might limit HMGB1 binding to RAGE, thus impairing NF- $\kappa B$ activation (141). Thrombomodulin also enhances thrombin-mediated proteolytic degradation of HMGB1, reducing its pro-inflammatory activity (142). Since HMGB1 has been linked to the pathogenesis and/or progression of a large range of clinical disorders characterized by endothelial dysfunction, including sepsis and autoimmune diseases, the identification of thrombomodulin as a natural inhibitor of HMGB1 is of clinical importance $(140,142,143)$ (Table 1).
TABLE 1 | Comparison of some features of vascular inflammation in sepsis and ANCA-associated small-vessel systemic vasculitis.

\begin{tabular}{lll}
\hline & Sepsis & Vasculitis \\
\hline Platelet count & Frequently low & Normal \\
Neutrophil count & High & Normal \\
Platelet activation & Yes & Yes \\
Neutrophil activation & Yes & Yes \\
Apoptotic neutrophils in & Yes & No \\
circulation & & \\
Endothelial activation & Yes & Yes \\
Plasma thrombomodulin & Low & Normal or high \\
level & & \\
HMGB1 & High & High \\
NETs & High & Not documented in all \\
& & types of vasculitis
\end{tabular}

During acute phases of vessel inflammation, thrombomodulin expression on the endothelial surface decreases because of at least two mechanisms: (i) internalization by endocytosis (144) or (ii) cleavage by enzymes like neutrophil elastase or cathepsin G $(145,146)$. Indeed, high levels of plasma thrombomodulin charaterize patients with systemic vasculitis [e.g., see Ref. (147-149)]. Whether the soluble cleaved thrombomodulin maintains the ability to bind to HMGB1 and whether the complex retains biological activities remain to be established.

Several other mechanisms possibly contribute to quench the inflammatory and thrombogenic actions of HMGB1 in the blood. For example, the vagus nerve is a part of a reflex that prevents or neutralizes excessive inflammation in response to tissue injury and infection. Sepsis is a prototypical condition in which an early unrestrained production of cytokines initiates a systemic response involving chemokines, amines, and activation of the complement and of the coagulatory systems eventually leading to disrupted vascular integrity, hypotension, and shock. HMGB1 is a recognized player in the late phases of sepsis. Pioneering studies have shown that stimulation of the vagus nerve or administration of cholinergic agents or selective agonists of the alpha7 nicotinic acetylcholine receptor abate HMGB1 systemic levels and improve animal survival in endotoxaemia or upon cecal ligation and puncture, a standardized model of septic peritonitis. Activation of the alpha7 nicotinic acetylcholine receptors represents a key event in the antiinflammatory reflex, since it could be responsible for NF- $\mathrm{BB}$ nuclear translocation inhibition and thus for the restoration of homeostasis via suppression of pro-inflammatory cytokines generation and release $(150,151)$.

Of importance, this homeostatic system is activated even in sterile conditions, limiting the tissue damaging actions of NF- $\mathrm{KB}$ activation and HMGB1 expression in response to heart or hepatic ischemia-reperfusion injury $(152,153)$. The involvement of this pathway in systemic vasculitis has not been studied extensively so far. However, the accumulating evidence on the role that HMGB1 plays in persisting vascular inflammation (see above) and the possibility to pharmacologically exploit its anti-inflammatory actions (154) suggest that these 
studies might underpin the development of novel and effective therapeutic strategies.

\section{CONCLUDING REMARKS}

High mobility group box 1 is the best characterized alarmin, and its recognition plays a role that is more and more appreciated in several apparently unrelated conditions, in which inflammation does not abate with the original noxa but per se causes self-sustaining cell and tissue damage. Many factors contribute to make systemic vasculitis a particularly attractive scenario to dissect the complex biology of HMGB1. These include the characteristics of the pathogenesis of vasculitis, which stem from a deregulated interaction between leukocytes, endothelial cells, and vessel wall cells, and the increasing understanding of the mechanisms that physiologically regulate the homeostatic response of vessels to injury. Increasing knowledge of the immunobiology of HMGB1 willform a foundation for novel targeted immune strategies aimed at specifically targeting the early events in the natural history of vasculitis.

\section{REFERENCES}

1. Baldini M, Manfredi AA, Maugeri N. Targeting platelet-neutrophil interactions in giant-cell arteritis. Curr Pharm Des (2014) 20:567-74. doi:10.2174/1 38161282004140213144840

2. Maugeri N, Baldini M, Ramirez GA, Rovere-Querini P, Manfredi AA. Platelet-leukocyte deregulated interactions foster sterile inflammation and tissue damage in immune-mediated vessel diseases. Thromb Res (2012) 129:267-73. doi:10.1016/j.thromres.2011.12.001

3. Maugeri N, Rovere-Querini P, Baldini M, Sabbadini MG, Manfredi AA. Translational mini-review series on immunology of vascular disease: mechanisms of vascular inflammation and remodelling in systemic vasculitis. Clin Exp Immunol (2009) 156:395-404. doi:10.1111/j.1365-2249.2009.03921.x

4. Ramirez GA, Maugeri N, Sabbadini MG, Rovere-Querini P, Manfredi AA. Intravascular immunity as a key to systemic vasculitis: a work in progress, gaining momentum. Clin Exp Immunol (2014) 175:150-66. doi:10.1111/ cei. 12223

5. Maugeri N, Rovere-Querini P, Baldini M, Baldissera E, Sabbadini MG, Bianchi ME, et al. Oxidative stress elicits platelet/leukocyte inflammatory interactions via HMGB1: a candidate for microvessel injury in sytemic sclerosis. Antioxid Redox Signal (2014) 20:1060-74. doi:10.1089/ars.2013.5298

6. Maugeri N, Rovere-Querini P, Evangelista V, Covino C, Capobianco A, Bertilaccio MT, et al. Neutrophils phagocytose activated platelets in vivo: a phosphatidylserine, P-selectin, and \{beta\} 2 integrin-dependent cell clearance program. Blood (2009) 113:5254-65. doi:10.1182/blood-2008-09-180794

7. Manfredi AA, Rovere-Querini P, Maugeri N. Dangerous connections: neutrophils and the phagocytic clearance of activated platelets. Curr Opin Hematol (2010) 17:3-8. doi:10.1097/MOH.0b013e3283324f97

8. Mocsai A. Diverse novel functions of neutrophils in immunity, inflammation, and beyond. J Exp Med (2013) 210:1283-99. doi:10.1084/jem.20122220

9. Brinkmann V, Zychlinsky A. Neutrophil extracellular traps: is immunity the second function of chromatin? J Cell Biol (2012) 3(198):773-83. doi:10.1083/ jcb. 201203170

10. Radic M, Marion TN. Neutrophil extracellular chromatin traps connect innate immune response to autoimmunity. Semin Immunopathol (2013) 35:465-80. doi:10.1007/s00281-013-0376-6

11. Yipp BG, Kubes P. NETosis: how vital is it? Blood (2013) 122:2784-94. doi:10.1182/blood-2013-04-457671

12. Clark SR, Ma AC, Tavener SA, McDonald B, Goodarzi Z, Kelly MM, et al. Platelet TLR4 activates neutrophil extracellular traps to ensnare bacteria in septic blood. Nat Med (2007) 13:463-9. doi:10.1038/nm1565

13. Manfredi AA, Covino C, Rovere-Querini P, Maugeri N. Instructive influences of phagocytic clearance of dying cells on neutrophil extracellular trap generation. Clin Exp Immunol (2015) 179:24-9. doi:10.1111/cei.12320

\section{AUTHOR CONTRIBUTIONS}

NM, PR-Q, and AM selected the bibliography and wrote the manuscript.

\section{ACKNOWLEDGMENTS}

The authors wish to thank Dr. Maria Carla Panzeri and Dr. Cesare Covino for the excellent microscopies that have been carried out in ALEMBIC, an advanced microscopy laboratory established by the San Raffaele Scientific Institute and the Vita-Salute San Raffaele University.

\section{FUNDING}

The work in the authors laboratories was supported by the the Ministry of Higher Education and Research (MIUR) R0504, by the Ministry of Health, and by the Ricerca Finalizzata RF-2011-02352291.

14. Papayannopoulos V, Metzler KD, Hakkim A, Zychlinsky A. Neutrophil elastase and myeloperoxidase regulate the formation of neutrophil extracellular traps. J Cell Biol (2010) 191:677-91. doi:10.1083/jcb.201006052

15. Sreeramkumar V, Adrover JM, Ballesteros I, Cuartero MI, Rossaint J, Bilbao I, et al. Neutrophils scan for activated platelets to initiate inflammation. Science (2014) 5(346):1234-8. doi:10.1126/science.1256478

16. Dwivedi N, Radic M. Citrullination of autoantigens implicates NETosis in the induction of autoimmunity. Ann Rheum Dis (2014) 73:483-91. doi:10.1136/ annrheumdis-2013-203844

17. Leshner M, Wang S, Lewis C, Zheng H, Chen XA, Santy L, et al. PAD4 mediated histone hypercitrullination induces heterochromatin decondensation and chromatin unfolding to form neutrophil extracellular trap-like structures. Front Immunol (2012) 3:307. doi:10.3389/fimmu.2012.00307

18. McDonald B, Urrutia R, Yipp BG, Jenne CN, Kubes P. Intravascular neutrophil extracellular traps capture bacteria from the bloodstream during sepsis. Cell Host Microbe (2012) 13(12):324-33. doi:10.1016/j.chom.2012. 06.011

19. Hidalgo A, Chang J, Jang JE, Peired AJ, Chiang EY, Frenette PS. Heterotypic interactions enabled by polarized neutrophil microdomains mediate thromboinflammatory injury. Nat Med (2009) 15:384-91. doi:10.1038/nm.1939

20. Maugeri N, Campana L, Gavina M, Covino C, De Metrio M, Panciroli C, et al. Activated platelets present high mobility group box 1 to neutrophils, inducing autophagy and promoting the extrusion of neutrophil extracellular traps. J Thromb Haemost (2014) 12:2074-88. doi:10.1111/jth.12710

21. Maugeri N, Manfredi AA. Tissue factor expressed by neutrophils: another piece in the vascular inflammation puzzle. Semin Thromb Hemost (2015) 41:728-36. doi:10.1055/s-0035-1564043

22. Evangelista V, Manarini S, Dell'Elba G, Martelli N, Napoleone E, Di Santo A, et al. Clopidogrel inhibits platelet-leukocyte adhesion and platelet-dependent leukocyte activation. Thromb Haemost (2005) 94:568-77. doi:10.1160/ TH05-01-0020

23. Totani L, Evangelista V. Platelet-leukocyte interactions in cardiovascular disease and beyond. Arterioscler Thromb Vasc Biol (2010) 30:2357-61. doi:10.1161/ATVBAHA.110.207480

24. Totani L, Piccoli A, Manarini S, Federico L, Pecce R, Martelli N, et al. Srcfamily kinases mediate an outside-in signal necessary for beta2 integrins to achieve full activation and sustain firm adhesion of polymorphonuclear leucocytes tethered on E-selectin. Biochem J (2006) 396:89-98. doi:10.1042/ BJ20051924

25. Maugeri N, Rovere-Querini P, Slavich M, Coppi G, Doni A, Bottazzi B, et al. Early and transient release of leukocyte pentraxin 3 during acute myocardial infarction. J Immunol (2011) 187:970-9. doi:10.4049/jimmunol.1100261

26. Maugeri N, Rovere-Querini P, Evangelista V, Godino C, Demetrio $\mathrm{M}$, Baldini $\mathrm{M}$, et al. An intense and short-lasting burst of neutrophil 
activation differentiates early acute myocardial infarction from systemic inflammatory syndromes. PLoS One (2012) 7:e39484. doi:10.1371/journal. pone. 0039484

27. Maugeri N, Franchini S, Campana L, Baldini M, Ramirez GA, Sabbadini MG, et al. Circulating platelets as a source of the damage-associated molecular pattern HMGB1 in patients with systemic sclerosis. Autoimmunity (2012) 45(8):584-7. doi:10.3109/08916934.2012.719946

28. Rouhiainen A, Imai S, Rauvala H, Parkkinen J. Occurrence of amphoterin (HMG1) as an endogenous protein of human platelets that is exported to the cell surface upon platelet activation. Thromb Haemost (2000) 84:1087-94.

29. Mobarrez F, Antoniewicz L, Bosson JA, Kuhl J, Pisetsky DS, Lundback M. The effects of smoking on levels of endothelial progenitor cells and microparticles in the blood of healthy volunteers. PLoS One (2014) 9:e90314. doi:10.1371/ journal.pone.0090314

30. Varon D, Shai E. Platelets and their microparticles as key players in pathophysiological responses. J Thromb Haemost (2015) 13(Suppl 1):S40-6. doi:10.1111/jth.12976

31. Manfredi AA, Baldini M, Camera M, Baldissera E, Brambilla M, Peretti G, et al. Anti-TNFalpha agents curb platelet activation in patients with rheumatoid arthritis. Ann Rheum Dis (2016). doi:10.1136/annrheumdis-2015-208442

32. von Bruhl ML, Stark K, Steinhart A, Chandraratne S, Konrad I, Lorenz $\mathrm{M}$, et al. Monocytes, neutrophils, and platelets cooperate to initiate and propagate venous thrombosis in mice in vivo. J Exp Med (2012) 209:819-35. doi:10.1084/jem.20112322

33. Pilsczek FH, Salina D, Poon KK, Fahey C, Yipp BG, Sibley CD, et al. A novel mechanism of rapid nuclear neutrophil extracellular trap formation in response to Staphylococcus aureus. JImmunol (2010) 185:7413-25. doi:10.4049/jimmunol.1000675

34. Grayson PC, Kaplan MJ. At the bench: neutrophil extracellular traps (NETs) highlight novel aspects of innate immune system involvement in autoimmune diseases. J Leukoc Biol (2015) 99:253-64. doi:10.1189/jlb.5BT0615-247R

35. Lin AM, Rubin CJ, Khandpur R, Wang JY, Riblett M, Yalavarthi S, et al. Mast cells and neutrophils release IL-17 through extracellular trap formation in psoriasis. J Immunol (2011) 187:490-500. doi:10.4049/jimmunol.1100123

36. Metzler KD, Fuchs TA, Nauseef WM, Reumaux D, Roesler J, Schulze I, et al. Myeloperoxidase is required for neutrophil extracellular trap formation: implications for innate immunity. Blood (2011) 117:953-9. doi:10.1182/ blood-2010-06-290171

37. Knight JS, Luo W, O’Dell AA, Yalavarthi S, Zhao W, Subramanian V, et al. Peptidylarginine deiminase inhibition reduces vascular damage and modulates innate immune responses in murine models of atherosclerosis. Circ Res (2014) 14(114):947-56. doi:10.1161/CIRCRESAHA.114.303312

38. Knight JS, Subramanian V, O'Dell AA, Yalavarthi S, Zhao W, Smith CK, et al. Peptidylarginine deiminase inhibition disrupts NET formation and protects against kidney, skin and vascular disease in lupus-prone MRL/lpr mice. Ann Rheum Dis (2015) 74:2199-206. doi:10.1136/ annrheumdis-2014-205365

39. Farrera C, Fadeel B. Macrophage clearance of neutrophil extracellular traps is a silent process. J Immunol (2013) 1(191):2647-56. doi:10.4049/ jimmunol.1300436

40. Leffler J, Martin M, Gullstrand B, Tyden H, Lood C, Truedsson L, et al. Neutrophil extracellular traps that are not degraded in systemic lupus erythematosus activate complement exacerbating the disease. J Immunol (2012) 188:3522-31. doi:10.4049/jimmunol.1102404

41. Chrysanthopoulou A, Mitroulis I, Apostolidou E, Arelaki S, Mikroulis D, Konstantinidis T, et al. Neutrophil extracellular traps promote differentiation and function of fibroblasts. J Pathol (2014) 233:294-307. doi:10.1002/ path. 4359

42. de Souza AW, Abdulahad WH, Sosicka P, Bijzet J, Limburg PC, Stegeman CA, et al. Are urinary levels of high mobility group box 1 markers of active nephritis in anti-neutrophil cytoplasmic antibody-associated vasculitis? Clin Exp Immunol (2014) 178:270-8. doi:10.1111/cei.12422

43. Kaplan MJ, Radic M. Neutrophil extracellular traps: double-edged swords of innate immunity. JImmunol (2012) 15(189):2689-95. doi:10.4049/ jimmunol.1201719

44. Neeli I, Khan SN, Radic M. Histone deimination as a response to inflammatory stimuli in neutrophils. J Immunol (2008) 180:1895-902. doi:10.4049/ jimmunol.180.3.1895
45. Neeli I, Radic M. Knotting the NETs: analyzing histone modifications in neutrophil extracellular traps. Arthritis Res Ther (2012) 14:115. doi:10.1186/ ar3773

46. Wang $\mathrm{H}$, Wang $\mathrm{C}$, Zhao MH, Chen M. Neutrophil extracellular traps can activate alternative complement pathways. Clin Exp Immunol (2015) 181:518-27. doi:10.1111/cei.12654

47. Pinegin B, Vorobjeva N, Pinegin V. Neutrophil extracellular traps and their role in the development of chronic inflammation and autoimmunity. Autoimmun Rev (2015) 14:633-40. doi:10.1016/j.autrev.2015.03.002

48. Apostolidou E, Skendros P, Kambas K, Mitroulis I, Konstantinidis T, Chrysanthopoulou A, et al. Neutrophil extracellular traps regulate IL-1betamediated inflammation in familial Mediterranean fever. Ann Rheum Dis (2016) 75:269-77. doi:10.1136/annrheumdis-2014-205958

49. Kambas K, Chrysanthopoulou A, Vassilopoulos D, Apostolidou E, Skendros P, Girod A, et al. Tissue factor expression in neutrophil extracellular traps and neutrophil derived microparticles in antineutrophil cytoplasmic antibody associated vasculitis may promote thromboinflammation and the thrombophilic state associated with the disease. Ann Rheum Dis (2014) 73:1854-63. doi:10.1136/annrheumdis-2013-203430

50. Knight JS, Zhao W, Luo W, Subramanian V, O'Dell AA, Yalavarthi S, et al. Peptidylarginine deiminase inhibition is immunomodulatory and vasculoprotective in murine lupus. J Clin Invest (2013) 123:2981-93. doi:10.1172/ JCI67390

51. Bianchi ME, Manfredi AA. How macrophages ring the inflammation alarm. Proc Natl Acad Sci U S A (2014) 25(111):2866-7. doi:10.1073/ pnas. 1324285111

52. Lu B, Antoine DJ, Kwan K, Lundback P, Wahamaa H, Schierbeck H, et al. JAK/STAT1 signaling promotes HMGB1 hyperacetylation and nuclear translocation. Proc Natl Acad Sci U S A (2014) 111:3068-73. doi:10.1073/ pnas. 1316925111

53. Venereau E, Ceriotti C, Bianchi ME. DAMPs from cell death to new life. Front Immunol (2015) 6:422. doi:10.3389/fimmu.2015.00422

54. Tang D, Kang R, Livesey KM, Cheh CW, Farkas A, Loughran P, et al. Endogenous HMGB1 regulates autophagy. J Cell Biol (2010) 190:881-92. doi:10.1083/jcb.200911078

55. Bianchi ME, Manfredi AA. High-mobility group box 1 (HMGB1) protein at the crossroads between innate and adaptive immunity. Immunol Rev (2007) 220:35-46. doi:10.1111/j.1600-065X.2007.00574.x

56. Vogel S, Bodenstein R, Chen Q, Feil S, Feil R, Rheinlaender J, et al. Plateletderived HMGB1 is a critical mediator of thrombosis. JClin Invest (2015) 125:4638-54. doi:10.1172/JCI81660

57. Yang X, Wang H, Zhang M, Liu J, Lv B, Chen F. HMGB1: a novel protein that induced platelets active and aggregation via toll-like receptor-4, NF-kappaB and cGMP dependent mechanisms. Diagn Pathol (2015) 10:134. doi:10.1186/ s13000-015-0348-3

58. Castiglioni A, Canti V, Rovere-Querini P, Manfredi AA. High-mobility group box 1 (HMGB1) as a master regulator of innate immunity. Cell Tissue Res (2011) 343:189-99. doi:10.1007/s00441-010-1033-1

59. Venereau E, Casalgrandi M, Schiraldi M, Antoine DJ, Cattaneo A, De Marchis F, et al. Mutually exclusive redox forms of HMGB1 promote cell recruitment or proinflammatory cytokine release. J Exp Med (2012) 27(209):1519-28. doi:10.1084/jem.20120189

60. Vezzoli M, Castellani P, Campana L, Corna G, Bosurgi L, Manfredi AA, et al. Redox remodeling: a candidate regulator of HMGB1 function in injured skeletal muscle. Ann N Y Acad Sci (2010) 1209:83-90. doi:10.1111/j.1749-6632.2010.05748.x

61. Vezzoli M, Castellani P, Corna G, Castiglioni A, Bosurgi L, Monno A, et al. HMGB1 release and redox regulation accompany regeneration and remodeling of skeletal muscle. Antioxid Redox Signal (2011) 15(8):2161-74. doi:10.1089/ars.2010.3341

62. Hreggvidsdottir HS, Lundberg AM, Aveberger AC, Klevenvall L, Andersson U, Harris HE. High mobility group box protein 1 (HMGB1)-partner molecule complexes enhance cytokine production by signaling through the partner molecule receptor. Mol Med (2012) 18:224-30. doi:10.2119/ molmed.2011.00327

63. Wahamaa H, Schierbeck H, Hreggvidsdottir HS, Palmblad K, Aveberger AC, Andersson U, et al. High mobility group box protein 1 in complex with lipopolysaccharide or IL-1 promotes an increased inflammatory 
phenotype in synovial fibroblasts. Arthritis Res Ther (2011) 13:R136. doi:10.1186/ar3450

64. Campana L, Bosurgi L, Bianchi ME, Manfredi AA, Rovere-Querini P. Requirement of HMGB1 for stromal cell-derived factor-1/CXCL12dependent migration of macrophages and dendritic cells. JLeukoc Biol (2009) 86:609-15. doi:10.1189/jlb.0908576

65. Schiraldi M, Raucci A, Munoz LM, Livoti E, Celona B, Venereau E, et al. HMGB1 promotes recruitment of inflammatory cells to damaged tissues by forming a complex with CXCL12 and signaling via CXCR4. J Exp Med (2012) 12(209):551-63. doi:10.1084/jem.20111739

66. Andersson U, Harris HE. The role of HMGB1 in the pathogenesis of rheumatic disease. Biochim Biophys Acta (2010) 1799:141-8. doi:10.1016/j. bbagrm.2009.11.003

67. Grayson PC, Maksimowicz-McKinnon K, Clark TM, Tomasson G, Cuthbertson D, Carette S, et al. Distribution of arterial lesions in Takayasu's arteritis and giant cell arteritis. Ann Rheum Dis (2012) 71:1329-34. doi:10.1136/annrheumdis-2011-200795

68. Weyand CM, Liao YJ, Goronzy JJ. The immunopathology of giant cell arteritis: diagnostic and therapeutic implications. J Neuroophthalmol (2012) 32:259-65. doi:10.1097/WNO.0b013e318268aa9b

69. Foroozan R, Danesh-Meyer H, Savino PJ, Gamble G, Mekari-Sabbagh ON, Sergott RC. Thrombocytosis in patients with biopsy-proven giant cell arteritis. Ophthalmology (2002) 109:1267-71. doi:10.1016/S0161-6420(02)01076-X

70. Kale N, Eggenberger E. Diagnosis and management of giant cell arteritis: a review. Curr Opin Ophthalmol (2010) 21:417-22. doi:10.1097/ ICU.0b013e32833eae8b

71. Weyand CM, Kaiser M, Yang H, Younge B, Goronzy JJ. Therapeutic effects of acetylsalicylic acid in giant cell arteritis. Arthritis Rheum (2002) 46:457-66. doi:10.1002/art.10071

72. Nesher G, Berkun Y, Mates M, Baras M, Rubinow A, Sonnenblick M. Lowdose aspirin and prevention of cranial ischemic complications in giant cell arteritis. Arthritis Rheum (2004) 50:1332-7. doi:10.1002/art.20171

73. Lee MS, Smith SD, Galor A, Hoffman GS. Antiplatelet and anticoagulant therapy in patients with giant cell arteritis. Arthritis Rheum (2006) 54:3306-9. doi:10.1002/art.22141

74. Mollan SP, Sharrack N, Burdon MA, Denniston AK. Aspirin as adjunctive treatment for giant cell arteritis. Cochrane Database Syst Rev (2014) 8:CD010453. doi:10.1002/14651858.CD010453.pub2

75. Berger CT, Wolbers M, Meyer P, Daikeler T, Hess C. High incidence of severe ischaemic complications in patients with giant cell arteritis irrespective of platelet count and size, and platelet inhibition. Rheumatology (Oxford) (2009) 48:258-61. doi:10.1093/rheumatology/ken480

76. Gonzalez-Gay MA, Barros S, Lopez-Diaz MJ, Garcia-Porrua C, SanchezAndrade A, Llorca J. Giant cell arteritis: disease patterns of clinical presentation in a series of 240 patients. Medicine (Baltimore) (2005) 84:269-76. doi:10.1097/01.md.0000180042.42156.d1

77. Maugeri N, Baldini M, Rovere-Querini P, Maseri A, Sabbadini MG, Manfredi AA. Leukocyte and platelet activation in patients with giant cell arteritis and polymyalgia rheumatica: a clue to thromboembolic risks? Autoimmunity (2009) 42:386-8. doi:10.1080/08916930902832629

78. Di Comite G, Previtali P, Rossi CM, Dell'Antonio G, Rovere-Querini P, Praderio L, et al. High blood levels of chromogranin A in giant cell arteritis identify patients refractory to corticosteroid treatment. Ann Rheum Dis (2009) 68:293-5. doi:10.1136/ard.2007.086587

79. Baldini M, Maugeri N, Ramirez GA, Giacomassi C, Castiglioni A, PrietoGonzalez S, et al. Selective up-regulation of the soluble pattern-recognition receptor pentraxin 3 and of vascular endothelial growth factor in giant cell arteritis: relevance for recent optic nerve ischemia. Arthritis Rheum (2012) 64:854-65. doi:10.1002/art.33411

80. Manfredi AA, Rovere-Querini P, Bottazzi B, Garlanda C, Mantovani A. Pentraxins, humoral innate immunity and tissue injury. Curr Opin Immunol (2008) 20:538-44. doi:10.1016/j.coi.2008.05.004

81. Chiba S, Baghdadi M, Akiba H, Yoshiyama H, Kinoshita I, Dosaka-Akita H, et al. Tumor-infiltrating DCs suppress nucleic acid-mediated innate immune responses through interactions between the receptor TIM-3 and the alarmin HMGB1. Nat Immunol (2012) 13:832-42. doi:10.1038/ni.2376

82. Dumitriu IE, Baruah P, Bianchi ME, Manfredi AA, Rovere-Querini P. Requirement of HMGB1 and RAGE for the maturation of human plasmacytoid dendritic cells. Eur J Immunol (2005) 35:2184-90. doi:10.1002/ eji.200526066

83. Dumitriu IE, Baruah P, Valentinis B, Voll RE, Herrmann M, Nawroth PP, et al. Release of high mobility group box 1 by dendritic cells controls $\mathrm{T}$ cell activation via the receptor for advanced glycation end products. J Immunol (2005) 174:7506-15. doi:10.4049/jimmunol.174.12.7506

84. Dumitriu IE, Bianchi ME, Bacci M, Manfredi AA, Rovere-Querini P. The secretion of HMGB1 is required for the migration of maturing dendritic cells. J Leukoc Biol (2007) 81:84-91. doi:10.1189/jlb.0306171

85. Rovere-Querini P, Capobianco A, Scaffidi P, Valentinis B, Catalanotti F, Giazzon M, et al. HMGB1 is an endogenous immune adjuvant released by necrotic cells. EMBO Rep (2004) 5:825-30. doi:10.1038/ sj.embor.7400205

86. Dagna L, Salvo F, Tiraboschi M, Bozzolo EP, Franchini S, Doglioni C, et al. Pentraxin-3 as a marker of disease activity in Takayasu arteritis. Ann Intern Med (2011) 4(155):425-33. doi:10.7326/0003-4819-155-7-201110040-00005

87. Tombetti E, Di Chio MC, Sartorelli S, Papa M, Salerno A, Bottazzi B, et al. Systemic pentraxin-3 levels reflect vascular enhancement and progression in Takayasu arteritis. Arthritis Res Ther (2014) 16:479. doi:10.1186/ s13075-014-0479-z

88. de Souza AW, van der Geest KS, Brouwer E, Pinheiro FA, Oliveira AC, Sato EI, et al. High mobility group box 1 levels in large vessel vasculitis are not associated with disease activity but are influenced by age and statins. Arthritis Res Ther (2015) 17:158. doi:10.1186/s13075-015-0672-8

89. de Souza AW, Westra J, Limburg PC, Bijl M, Kallenberg CG. HMGB1 in vascular diseases: its role in vascular inflammation and atherosclerosis. Autoimmun Rev (2012) 11:909-17. doi:10.1016/j.autrev.2012.03.007

90. Bruchfeld A, Wendt M, Bratt J, Qureshi AR, Chavan S, Tracey KJ, et al. Highmobility group box-1 protein (HMGB1) is increased in antineutrophilic cytoplasmatic antibody (ANCA)-associated vasculitis with renal manifestations. Mol Med (2011) 17:29-35. doi:10.2119/molmed.2010.00132

91. Wang C, de Souza AW, Westra J, Bijl M, Chen M, Zhao MH, et al. Emerging role of high mobility group box 1 in ANCA-associated vasculitis. Autoimmun $\operatorname{Rev}(2015)$ 14:1057-65. doi:10.1016/j.autrev.2015.07.010

92. Wang C, Gou SJ, Chang DY, Yu F, Zhao MH, Chen M. Association of circulating level of high mobility group box 1 with disease activity in antineutrophil cytoplasmic autoantibody-associated vasculitis. Arthritis Care Res (2013) 65:1828-34. doi:10.1002/acr.22187

93. Wibisono D, Csernok E, Lamprecht P, Holle JU, Gross WL, Moosig F. Serum HMGB1 levels are increased in active Wegener's granulomatosis and differentiate between active forms of ANCA-associated vasculitis. Ann Rheum Dis (2010) 69:1888-9. doi:10.1136/ard.2009.119172

94. Henes FO, Chen Y, Bley TA, Fabel M, Both M, Herrmann K, et al. Correlation of serum level of high mobility group box 1 with the burden of granulomatous inflammation in granulomatosis with polyangiitis (Wegener's). Ann Rheum Dis (2011) 70:1926-9. doi:10.1136/ard.2010.146456

95. Ma TT, Wang H, Wang C, Chang DY, Zhao MH, Chen M. Urinary levels of high mobility group box-1 are associated with disease activity in antineutrophil cytoplasmic autoantibody-associated vasculitis. PLoS One (2015) 10:e0123586. doi:10.1371/journal.pone. 0123586

96. de Souza A, Westra J, Bijzet J, Limburg PC, Stegeman CA, Bijl M, et al. Is serum HMGB1 a biomarker in ANCA-associated vasculitis? Arthritis Res Ther (2013) 15:R104. doi:10.1186/ar4284

97. Wang C, Wang H, Chang DY, Hao J, Zhao MH, Chen M. High mobility group box 1 contributes to anti-neutrophil cytoplasmic antibody-induced neutrophils activation through receptor for advanced glycation end products (RAGE) and toll-like receptor 4. Arthritis Res Ther (2015) 17:64. doi:10.1186/ s13075-015-0587-4

98. Halbwachs L, Lesavre P. Endothelium-neutrophil interactions in ANCAassociated diseases. J Am Soc Nephrol (2012) 23:1449-61. doi:10.1681/ ASN.2012020119

99. Ma YH, Ma TT, Wang C, Wang H, Chang DY, Chen M, et al. High-mobility group box 1 potentiates antineutrophil cytoplasmic antibody-inducing neutrophil extracellular traps formation. Arthritis Res Ther (2016) 18:2. doi:10.1186/s13075-015-0903-z

100. Eguchi T, Nomura Y, Hashiguchi T, Masuda K, Arata M, Hazeki D, et al. An elevated value of high mobility group box 1 is a potential marker for poor response to high-dose of intravenous immunoglobulin treatment in patients 
with Kawasaki syndrome. Pediatr Infect Dis J (2009) 28:339-41. doi:10.1097/ INF.0b013e31818ffe60

101. Hoshina T, Kusuhara K, Ikeda K, Mizuno Y, Saito M, Hara T. High mobility group box 1 (HMGB1) and macrophage migration inhibitory factor (MIF) in Kawasaki disease. Scand J Rheumatol (2008) 37:445-9. doi:10.1080/03009740802144143

102. Yoshizaki A, Komura K, Iwata Y, Ogawa F, Hara T, Muroi E, et al. Clinical significance of serum HMGB-1 and sRAGE levels in systemic sclerosis: association with disease severity. J Clin Immunol (2009) 29:180-9. doi:10.1007/ s10875-008-9252-x

103. Nin JW, Ferreira I, Schalkwijk CG, Jorsal A, Prins MH, Parving HH, et al. Higher plasma high-mobility group box 1 levels are associated with incident cardiovascular disease and all-cause mortality in type 1 diabetes: a 12 year follow-up study. Diabetologia (2012) 55:2489-93. doi:10.1007/ s00125-012-2622-1

104. Schaper NC, Havekes B. Diabetes: impaired damage control. Diabetologia (2012) 55:18-20. doi:10.1007/s00125-011-2368-1

105. DeVerse JS, Bailey KA, Jackson KN, Passerini AG. Shear stress modulates RAGE-mediated inflammation in a model of diabetes-induced metabolic stress. Am J Physiol Heart Circ Physiol (2012) 15(302):H2498-508. doi:10.1152/ajpheart.00869.2011

106. Kanellakis P, Agrotis A, Kyaw TS, Koulis C, Ahrens I, Mori S, et al. Highmobility group box protein 1 neutralization reduces development of diet-induced atherosclerosis in apolipoprotein e-deficient mice. Arterioscler Thromb Vasc Biol (2011) 31:313-9. doi:10.1161/ATVBAHA.110.218669

107. Yan XX, Lu L, Peng WH, Wang LJ, Zhang Q, Zhang RY, et al. Increased serum HMGB1 level is associated with coronary artery disease in nondiabetic and type 2 diabetic patients. Atherosclerosis (2009) 205:544-8. doi:10.1016/j. atherosclerosis.2008.12.016

108. Han J, Zhong J, Wei W, Wang Y, Huang Y, Yang P, et al. Extracellular high-mobility group box 1 acts as an innate immune mediator to enhance autoimmune progression and diabetes onset in NOD mice. Diabetes (2008) 57:2118-27. doi:10.2337/db07-1499

109. Li M, Song L, Gao X, Chang W, Qin X. Toll-like receptor 4 on islet beta cells senses expression changes in high-mobility group box 1 and contributes to the initiation of type 1 diabetes. Exp Mol Med (2012) 30(44):260-7. doi:10.3858/emm.2012.44.4.021

110. Kruger B, Yin N, Zhang N, Yadav A, Coward W, Lal G, et al. Islet-expressed TLR2 and TLR4 sense injury and mediate early graft failure after transplantation. Eur J Immunol (2010) 40:2914-24. doi:10.1002/eji.201040601

111. Matsuoka N, Itoh T, Watarai H, Sekine-Kondo E, Nagata N, Okamoto K, et al. High-mobility group box 1 is involved in the initial events of early loss of transplanted islets in mice. J Clin Invest (2010) 120:735-43. doi:10.1172/ JCI41360

112. Nicolosi PA, Tombetti E, Maugeri N, Rovere-Querini P, Brunelli S, Manfredi AA. Vascular remodelling and mesenchymal transition in systemic sclerosis. Stem Cells Int (2016) 2016:4636859. doi:10.1155/2016/4636859

113. Andrassy M, Volz HC, Igwe JC, Funke B, Eichberger SN, Kaya Z, et al. Highmobility group box-1 in ischemia-reperfusion injury of the heart. Circulation (2008) 24(117):3216-26. doi:10.1161/CIRCULATIONAHA.108.769331

114. Ding HS, Yang J, Gong FL, Yang J, Ding JW, Li S, et al. High mobility group [corrected] box 1 mediates neutrophil recruitment in myocardial ischemia-reperfusion injury through toll like receptor 4-related pathway. Gene (2012) 509:149-53. doi:10.1016/j.gene.2012.07.072

115. Evankovich J, Cho SW, Zhang R, Cardinal J, Dhupar R, Zhang L, et al. High mobility group box 1 release from hepatocytes during ischemia and reperfusion injury is mediated by decreased histone deacetylase activity. J Biol Chem (2010) 17(285):39888-97. doi:10.1074/jbc.M110.128348

116. Levy RM, Mollen KP, Prince JM, Kaczorowski DJ, Vallabhaneni R, Liu S, et al. Systemic inflammation and remote organ injury following trauma require HMGB1. Am J Physiol Regul Integr Comp Physiol (2007) 293:R1538-44. doi:10.1152/ajpregu.00272.2007

117. Rabadi MM, Ghaly T, Goligorksy MS, Ratliff BB. HMGB1 in renal ischemic injury. Am J Physiol Renal Physiol (2012) 15(303):F873-85. doi:10.1152/ ajprenal.00092.2012

118. van Beijnum JR, Nowak-Sliwinska $P$, van den Boezem E, Hautvast $P$, Buurman WA, Griffioen AW. Tumor angiogenesis is enforced by autocrine regulation of high-mobility group box 1. Oncogene (2013) 32:363-74. doi:10.1038/ onc. 2012.49
119. Csernok E, Moosig F, Gross WL. Pathways to ANCA production: from differentiation of dendritic cells by proteinase 3 to B lymphocyte maturation in Wegener's granuloma. Clin Rev Allergy Immunol (2008) 34:300-6. doi:10.1007/s12016-007-8056-8

120. Kallenberg CG. Pathogenesis of PR3-ANCA associated vasculitis. J Autoimmun (2008) 30:29-36. doi:10.1016/j.jaut.2007.11.005

121. Rimbert M, Hamidou M, Braudeau C, Puechal X, Teixeira L, Caillon H, et al. Decreased numbers of blood dendritic cells and defective function of regulatory T cells in antineutrophil cytoplasmic antibody-associated vasculitis. PLoS One (2011) 6:e18734. doi:10.1371/journal.pone.0018734

122. PryshchepO,Ma-KrupaW, YoungeBR,GoronzyJJ,WeyandCM.Vessel-specific Toll-like receptor profiles in human medium and large arteries. Circulation (2008) 16(118):1276-84. doi:10.1161/CIRCULATIONAHA.108.789172

123. Arnaud L, Haroche J, Mathian A, Gorochov G, Amoura Z. Pathogenesis of Takayasu's arteritis: a 2011 update. Autoimmun Rev (2011) 11:61-7. doi:10.1016/j.autrev.2011.08.001

124. Biscetti F, Straface G, De Cristofaro R, Lancellotti S, Rizzo P, Arena V, et al. High-mobility group box-1 protein promotes angiogenesis after peripheral ischemia in diabetic mice through a VEGF-dependent mechanism. Diabetes (2010) 59:1496-505. doi:10.2337/db09-1507

125. Lolmede K, Campana L, Vezzoli M, Bosurgi L, Tonlorenzi R, Clementi E, et al. Inflammatory and alternatively activated human macrophages attract vessel-associated stem cells, relying on separate HMGB1- and MMP-9-dependent pathways. J Leukoc Biol (2009) 85:779-87. doi:10.1189/ jlb.0908579

126. Bierhaus A, Humpert PM, Morcos M, Wendt T, Chavakis T, Arnold B, et al. Understanding RAGE, the receptor for advanced glycation end products. J Mol Med (Berl) (2005) 83:876-86. doi:10.1007/s00109-005-0688-7

127. Allenbach Y, Seror R, Pagnoux C, Teixeira L, Guilpain P, Guillevin L, et al. High frequency of venous thromboembolic events in Churg-Strauss syndrome, Wegener's granulomatosis and microscopic polyangiitis but not polyarteritis nodosa: a systematic retrospective study on 1130 patients. Ann Rheum Dis (2009) 68:564-7. doi:10.1136/ard.2008.099051

128. Stassen PM, Derks RP, Kallenberg CG, Stegeman CA. Venous thromboembolism in ANCA-associated vasculitis - incidence and risk factors. Rheumatology (Oxford) (2008) 47:530-4. doi:10.1093/rheumatology/ken035

129. McCarthy LJ, Danielson C, Weidner J, Miraglia C. Chronic severe thrombotic thrombocytopenic purpura (TTP). Ther Apher (1999) 3:348-9.

130. Tomasson G, Lavalley M, Tanriverdi K, Finkielman JD, Davis JC Jr, Hoffman GS, et al. Relationship between markers of platelet activation and inflammation with disease activity in Wegener's granulomatosis. J Rheumatol (2011) 38:1048-54. doi:10.3899/jrheum.100735

131. Zarbock A, Ley K, McEver RP, Hidalgo A. Leukocyte ligands for endothelial selectins: specialized glycoconjugates that mediate rolling and signaling under flow. Blood (2011) 118:6743-51. doi:10.1182/blood-2011-07343566

132. Gupta AK, Joshi MB, Philippova M, Erne P, Hasler P, Hahn S, et al. Activated endothelial cells induce neutrophil extracellular traps and are susceptible to NETosis-mediated cell death. FEBS Lett (2010) 584:3193-7. doi:10.1016/j. febslet.2010.06.006

133. Fuchs TA, Brill A, Wagner DD. Neutrophil extracellular trap (NET) impact on deep vein thrombosis. Arterioscler Thromb Vasc Biol (2012) 32:1777-83. doi:10.1161/ATVBAHA.111.242859

134. Saffarzadeh M, Juenemann C, Queisser MA, Lochnit G, Barreto G, Galuska SP, et al. Neutrophil extracellular traps directly induce epithelial and endothelial cell death: a predominant role of histones. PLoS One (2012) 7:e32366. doi:10.1371/journal.pone.0032366

135. Rauvala $\mathrm{H}$, Rouhiainen A. Physiological and pathophysiological outcomes of the interactions of HMGB1 with cell surface receptors. Biochim Biophys Acta (2010) 1799:164-70. doi:10.1016/j.bbagrm.2009.11.012

136. Fiuza C, Bustin M, Talwar S, Tropea M, Gerstenberger E, Shelhamer JH, et al. Inflammation-promoting activity of HMGB1 on human microvascular endothelial cells. Blood (2003) 101:2652-60. doi:10.1182/blood-2002-05-1300

137. Treutiger CJ, Mullins GE, Johansson AS, Rouhiainen A, Rauvala HM, Erlandsson-Harris $\mathrm{H}$, et al. High mobility group 1 B-box mediates activation of human endothelium. J Intern Med (2003) 254:375-85. doi:10.1046/j.1365-2796.2003.01204.x

138. Bianchi ME, Manfredi AA. Immunology. Dangers in and out. Science (2009) 27(323):1683-4. doi:10.1126/science.1172794 
139. Chen GY, Tang J, Zheng P, Liu Y. CD24 and Siglec-10 selectively repress tissue damage-induced immune responses. Science (2009) 27(323):1722-5. doi:10.1126/science.1168988

140. Conway EM. Thrombomodulin and its role in inflammation. Semin Immunopathol (2012) 34:107-25. doi:10.1007/s00281-011-0282-8

141. Abeyama K, Stern DM, Ito Y, Kawahara K, Yoshimoto Y, Tanaka M, et al. The N-terminal domain of thrombomodulin sequesters high-mobility group-B1 protein, a novel antiinflammatory mechanism. J Clin Invest (2005) 115:1267-74. doi:10.1172/JCI22782

142. Ito T, Kawahara K, Okamoto K, Yamada S, Yasuda M, Imaizumi H, et al. Proteolytic cleavage of high mobility group box 1 protein by thrombin-thrombomodulin complexes. Arterioscler Thromb Vasc Biol (2008) 28:1825-30. doi:10.1161/ATVBAHA.107.150631

143. Esmon C. Do-all receptor takes on coagulation, inflammation. Nat Med (2005) 11:475-7. doi:10.1038/nm0505-475

144. Moore KL, Esmon CT, Esmon NL. Tumor necrosis factor leads to the internalization and degradation of thrombomodulin from the surface of bovine aortic endothelial cells in culture. Blood (1989) 73:159-65.

145. Esmon CT. Inflammation and the activated protein $\mathrm{C}$ anticoagulant pathway. Semin Thromb Hemost (2006) 32(Suppl 1):49-60. doi:10.1055/s2006-939554

146. Menashi S, Tribout B, Dosquet C, Le Toumelin P, Piette JC, Wechsler B, et al. Strong association between plasma thrombomodulin and pathergy test in Behcet disease. Ann Rheum Dis (2008) 67:892-3. doi:10.1136/ ard.2007.075143

147. de Leeuw K, Bijzet J, van der Graaf AM, Stegeman CA, Smit AJ, Kallenberg CG, et al. Patients with Wegener's granulomatosis: a long-term follow-up study. Clin Exp Rheumatol (2010) 28:18-23.

148. Monach PA, Tomasson G, Specks U, Stone JH, Cuthbertson D, Krischer J, et al. Circulating markers of vascular injury and angiogenesis in antineutrophil cytoplasmic antibody-associated vasculitis. Arthritis Rheum (2011) 63:3988-97. doi:10.1002/art.30615

149. Zycinska K, Wardyn KA, Zielonka TM, Krupa R, Lukas W. Clinical implications of serum thrombomodulin in PR3-ANCA-associated vasculitis. Eur JMed Res (2009) 14(Suppl 4):268-70. doi:10.1186/2047-783X-14-S4-268

150. Huston JM, Gallowitsch-Puerta M, Ochani M, Ochani K, Yuan R, RosasBallina $\mathrm{M}$, et al. Transcutaneous vagus nerve stimulation reduces serum high mobility group box 1 levels and improves survival in murine sepsis. Crit Care Med (2007) 35:2762-8. doi:10.1097/01.CCM.0000288102.15975.BA

151. Wang H, Liao H, Ochani M, Justiniani M, Lin X, Yang L, et al. Cholinergic agonists inhibit HMGB1 release and improve survival in experimental sepsis. Nat Med (2004) 10:1216-21. doi:10.1038/nm1124

152. Li F, Chen Z, Pan Q, Fu S, Lin F, Ren H, et al. The protective effect of PNU-282987, a selective alpha7 nicotinic acetylcholine receptor agonist, on the hepatic ischemia-reperfusion injury is associated with the inhibition of high-mobility group box 1 protein expression and nuclear factor kappaB activation in mice. Shock (2013) 39:197-203. doi:10.1097/ SHK.0b013e31827aalf6

153. Xiong J, Yuan YJ, Xue FS, Wang Q, Cheng Y, Li RP, et al. Postconditioning with alpha7nAChR agonist attenuates systemic inflammatory response to myocardial ischemia - reperfusion injury in rats. Inflammation (2012) 35:1357-64. doi:10.1007/s10753-012-9449-2

154. Bonaz B, Sinniger V, Pellissier S. Anti-inflammatory properties of the vagus nerve: potential therapeutic implications of vagus nerve stimulation. J Physiol (2016). doi:10.1113/JP271539

Conflict of Interest Statement: The authors declare that the research was conducted in the absence of any commercial or financial relationships that could be construed as a potential conflict of interest.

Copyright (C) 2016 Maugeri, Rovere-Querini and Manfredi. This is an open-access article distributed under the terms of the Creative Commons Attribution License (CC BY). The use, distribution or reproduction in other forums is permitted, provided the original author(s) or licensor are credited and that the original publication in this journal is cited, in accordance with accepted academic practice. No use, distribution or reproduction is permitted which does not comply with these terms. 